\title{
Identification of Owan Catchment Run-of-River Hydropower Potential Sites in Benin Owena River Basin Nigeria Using GIS And RS Procedures
}

\author{
Olatubosun Fasipe ${ }^{1,2, *} \quad$ Osadolor Izinyon $^{2} \quad$ Chukwudi Emeribe $^{3} \quad$ Idowu Ilaboya $^{2} \quad$ Victor Eniola $^{1}$ \\ Ebuwa Isagba $^{2} \quad$ Nicholas Uwadia $^{3}$ \\ 1.Energy Commission of Nigeria Central Business District, P.M.B 358, Garki, Abuja 900211, Nigeria \\ 2.Department of Civil Engineering, University of Benin, Benin City, Edo State 300283, Nigeria \\ 3.National Centre for Energy and Environment, University of Benin, Benin City, Edo State 300283, Nigeria
}

\begin{abstract}
Hydropower is recognized internationally as a source of clean, affordable, and reliable energy that has contributed in a significant way to the global energy supply mix but unfortunately, this is not the case in Nigeria considering hydropower potential of $15 \mathrm{GW}$ where only approximately $2 \mathrm{GW}(13 \%)$ has been harnessed. Nigeria Small Hydropower (SHP) level is low, as less than $0.1 \mathrm{GW}$ out of $3.5 \mathrm{GW}$ SHP potential is available in a country of over 200 million people with potentials of 333BCM of surface water annually which can be used to increase energy access especially in the rural area where the percentage in 2018 is 34. In this study, Natural Resources Conservation Service - Curve Number (NRCS-CN) method which calculates surface runoff volume for a particular rainfall event in a watershed was applied in conjunction with Remote Sensing (RS) and Geographic Information System (GIS). Land Use Land Cover (LULC) classes of Owan Sub-basin were delineated from Landsat 8 satellite Image using Image Classification procedure and integrated with the hydrologic soil group (HSG) of the sub-basin in a GIS environment to obtain runoff Curve Numbers (CNs) for this study. The estimated CNs and rainfall data of Precipitation Estimation from Remotely Sensed Information using Artificial Neural Networks - Climate Data Record (PERSIANN - CDR) of the study area for the year 2018 were used to calculate the peak discharges over 125 mapped out points at $2 \mathrm{~km}$ interval in Owan river. The gauging station data correlates NRCS-CN with a coefficient of $68 \%$ while the Nigerian Meteorological Services Agency (NIMET) data compared with PERSIANN-CDR yielded a $70 \%$ correlation. Using the basin hydrometric indicators of $2 \%$ minimum slope and $10 \mathrm{~m}$ available head which must exist between two points before a site can be considered for ROR hydropower, 20 points were identified in Owan with power range from $423.015 \mathrm{~kW}$ to $5,456.646 \mathrm{~kW}$ at $92 \%$ available flow exceedance annually. This study revealed that NRCS-CN method combined with RS and GIS can simulate discharge successfully using watershed hydrometry in the absence of weak hydrological data. Also, owing to a significant degree of agreement between the observed and calculated runoff, the method, and models employed for this study are recommended for field applications in Benin-Owena River Basin, Nigeria at large, and other regions with data scarcity challenges hydrologically.
\end{abstract}

Keywords: run-of-river, hydropower potential, Remote Sensing, Geographic Information System, NRCS-CN model.

DOI: $10.7176 / \mathrm{CER} / 12-10-05$

Publication date:October $31^{\text {st }} 2020$

\section{Introduction}

Increasing request for energy, particularly from inexhaustible and green sources, encourages small hydropower (SHP) plants development and energizes interest in new investigation studies. Prefeasibility studies to survey hydropower potential generally convey enormous hesitations about the financial, technical, and eco-friendly practicability of the undeveloped potential (Larentis et al. 2010). Unlike the evaluation of single hydropower projects, where the site is characterized and other limit conditions are well defined, investigation of river basin presents a problem type where project location is not known and the energy potential in every site depends on the existing catchment harnessing plan in the same basin. Furthermore, the incorporated technical and environmental evaluation includes the appraisal of numerous conditions and spatially-dispersed data (Kusre et al 2010; Rojanamon, et al. 2009; Yi, et al. 2010; Dudhani et al. 2006). According to (Dudhani et al. 2006) a survey phase carefully carried out in a site gives administrators appropriate and correct details to arrive at the concluding set of choices with minimal impact of the hydropower exploitation over other activities, active infrastructure amenities, and the environment.

Within this scenario, Streams in developing countries including Nigeria are poorly gauged and lacking in critical hydrological information and data even though world's hydropower potential of about $12 \%$ is in Africa just $5 \%$ of this potential has been tapped (ESHA 2006); (FAO 2008). Also, where detailed baselines studies exist like in the Benin Owena River Basin through the publication of (BORBDA 1992; 1993; 1997; 2005; 2007), there is discontinuity in data gathering about existing sites. Moreover, the hydrological potential for SHP development 
of many streams and rivers in the rural areas are not studied and yet SHP can be a veritable source of efficient, reliable, and clean energy for rural communities when harnessed. There are many streams and rivers in Nigeria, but like many developing countries SHP deployment is minimal considering that out of the evaluated 3.5GW SHP utilizable potential existing in the country, less than $0.1 \mathrm{GW}$ has been tapped which represents approximately $2 \%$ (ECN 2014; Bala 2019; Ochigbo 2019).

The need to use renewable energies as a crucial tool becomes more urgent in the effort towards sustainable growth in developing territories of the world. In Nigeria, approximately 4,500MW of electricity is available in 2018 owing to technical, grid, and gas constraints out of $13.7 \mathrm{GW}$ electricity generation installed capacity in contrast with 51 GW South-Africa generation capacity (NESP 2019). Nigeria is positioned ninth in Africa in terms of hydropower potential with 32,450 GWh/yr. technically realistic hydropower energy (IJHD 2015; Oyedepo et al. 2018).

Improvements in GIS, RS, and hydrological modeling offer genuine, modern, and suitable data in the evaluation of hydropower resource potential. GIS environment makes it easier to collect and scrutinize information on land-use practice, geology, topography, and river morphology compare to regular field survey because GIS can deal with catchment characteristics with respect to a specific location and make available analysis about the impact zone of the hydropower project (Pandey et al. 2015).

Several scholars have applied GIS and RS techniques in hydropower study: (Feizizadeh et al. 2012) utilized GIS topographical and meteorological datasets in the Tabriz basin of Iran to calculate the supposed surface hydropower potential. The study reveals the highest potentials are in Mehran Roud river branches. (Chandra et al. 2013) applying geo-spatial techniques in Andhra Pradesh state spotted suitable location for micro-hydropower station locations. (Pandey et al. 2015) in their study of Mat River Basin, southern Mizoram, India employs spatial technologies and hydrological models to evaluate water accessibility, and obtained results show hydropower potential of the basin was successfully investigated utilizing GIS tools, satellite data, and SWAT (Soil and Water Assessment Tool) model. Also, RS data and GIS-based technologies have gained more influence across various countries with their application in spotting and selecting hydroelectric prospects of distinct classes, for instance, pumped storage hydropower systems in Ireland (Connolly et al. 2010), small run-of-river (ROR) schemes in Thailand (Rojanamon et al. 2009), US (Hall et al. 2004) and Brazil (Avila et al. 2007), and water retention facility (dams) in India (Kusre et al. 2010), Brazil (Larentis et al. 2010), South Korea (Yi et al. 2010) and South Africa (Ballance et al. 2000).

Meanwhile, in any significant SHP (Figure 1) project, data on topographical, hydrological, and geological characteristics of the basin of concern, techno-economic, and social characteristics of project beneficiaries are fundamental and prerequisite. Owan sub-basin is gifted with enormous surface water resources which can be exploited for hydropower projects in the Sub-basin. Unfortunately, not much is known regarding the hydropower viability of the sub-basin in terms of potentials for SHP projects using GIS and RS techniques and this necessitates the study.



Figure 1: ROR SHP Scheme showing the components (Panlenlab 2017) 


\section{Methodology}

This paper taking into account technical, economic, and environmental vulnerabilities of Owan sub-basin describes the application of GIS \& RS tools together with NRCS-CN rainfall-runoff model in the selection of sustainable hydropower potential sites and categorizing them based on available power annually amidst insufficient comprehensive hydrological data.

\subsection{The Study Area}

Owan sub-basin is one of the sub-catchments of the Benin-Owena River Basin Development Authority (BORBDA) Catchment Area. Owan sub-basins (Figure 2) is on 6 $4^{\prime} 52.039^{\prime \prime}$ to $5^{\circ} 43^{\prime} 51.465^{\prime \prime}$ East longitude and $7^{\circ} 8^{\prime} 58.834^{\prime \prime}$ to $6^{\circ} 39^{\prime} 53.906$ "North latitude with elevation coverage 50 - 400m above Mean Sea Level (MSL), yearly precipitation $1630-2133 \mathrm{~mm}$, slope class 0 to $42.7 \%$, Land Use Land Cover (LULC) that varies from dense and mixed vegetation to Build up areas with loamy and sandy loamy as the predominant soil which spans a total area of $1216.50 \mathrm{~km}^{2}$.

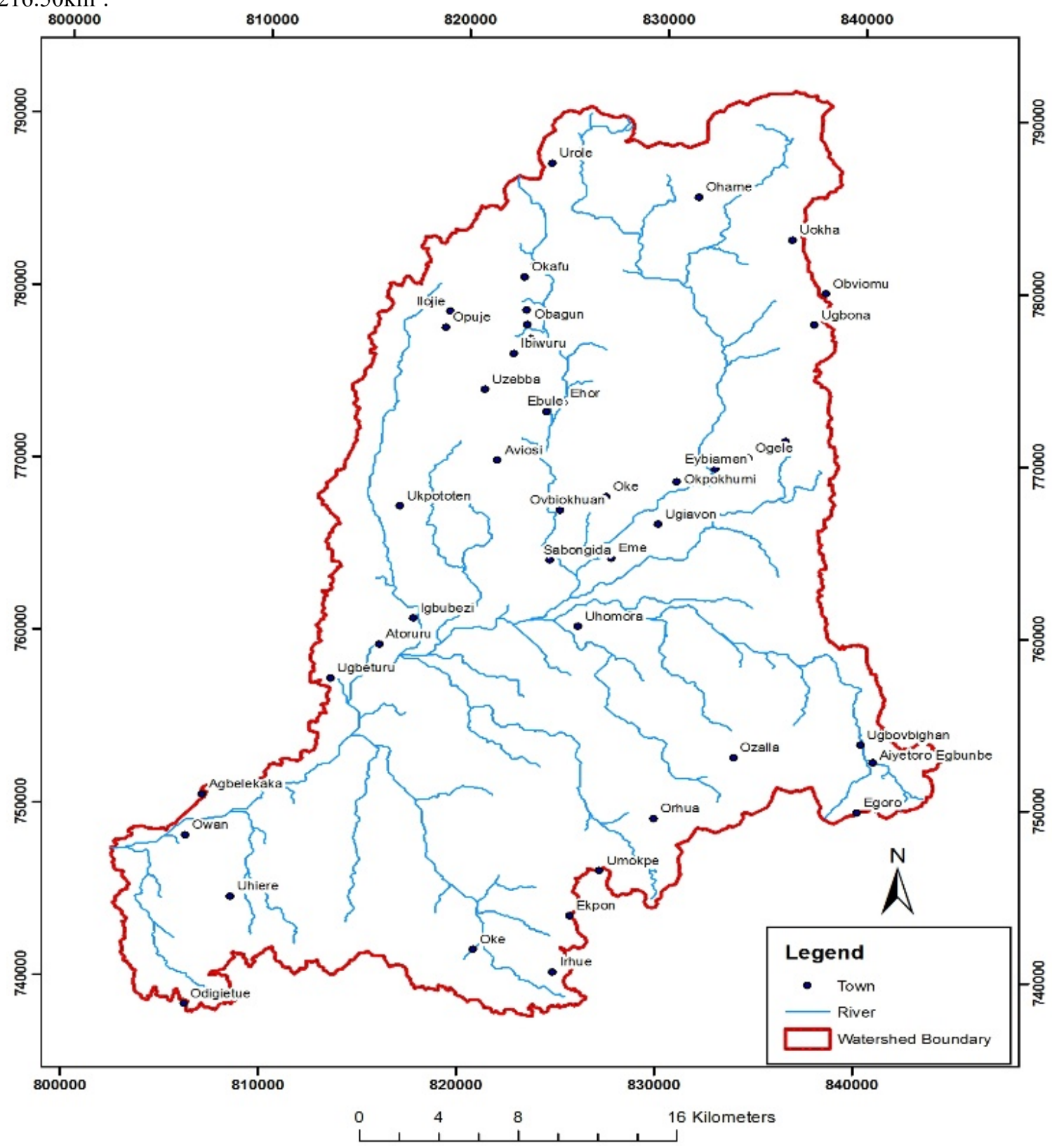

Figure 2: Owan Sub-basin Watershed map figure 3 .

The step by step procedure to determine the SHP potential of Owan sub-basin is presented as a flow chart in 


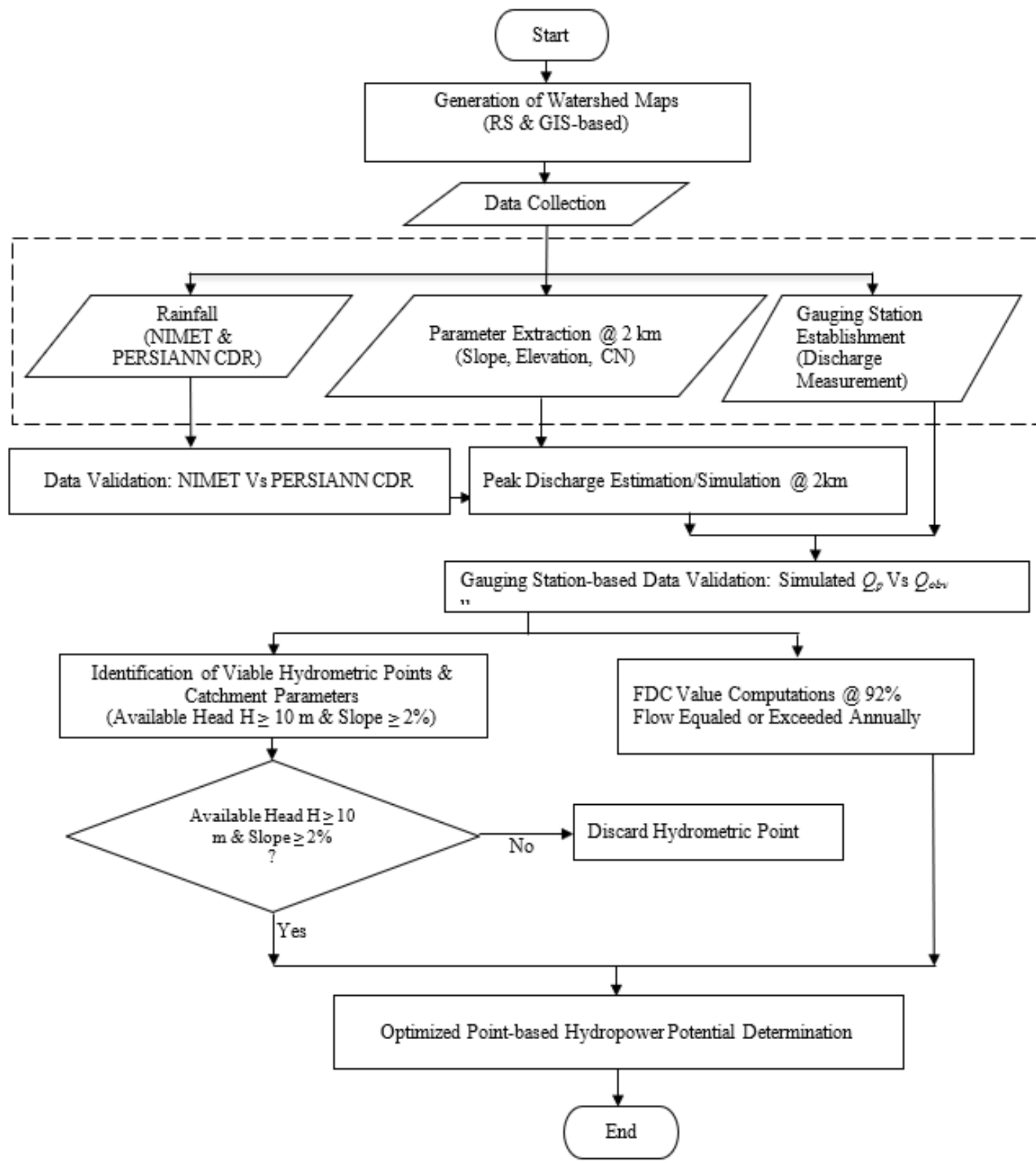

Figure 3: Methodology flow chart diagram (Fasipe and Izinyon 2020)

\subsection{Data collection}

\subsubsection{Rainfall Data}

The rainfall data which consists of monthly series (secondary data) were obtained from Nigerian Meteorological Services Agency (NIMET) and the Precipitation Estimation from Remotely Sensed Information using Artificial Neural Networks - Climate Data Record (PERSIANN-CDR). The $0.25^{\circ} \times 0.25^{\circ}$ grid cell satellite-based rainfall data of the year 2018 were obtained using RS \& GIS techniques from PERSIANN-CDR and compared utilizing Pearson's Product Moment Correlation statistics at 0.05 significance level with NIMET data from Benin Synoptic station which is close to the study site in order to use the former to achieve spatial results across Owan Subcatchment.

\subsubsection{Slope / Elevation from Digital Elevation Model (DEM)}

The elevation raster for the study area was generated from the DEM using the create elevation tool. Also, slope classes were generated using the Slope tool out of the Spatial Analyst toolbox. The DEM data of the Shuttle Radar Topography Mission (SRTM) were used to compute slope and elevation for the study area. 


\subsubsection{Soil \& LULC Classifications and Curve Number (CN) Estimation}

The Curve Number (CN) is a physical constant lacking unit (Verma et al. 2017). The runoff CN of hydrologic soil cover is expressed in terms of land cover, soil type, and changes based on antecedent soil moisture conditions (AMC) namely: AMC-I, AMC-II, and AMC-III. In determining the $\mathrm{CN}$, basin characteristics such as information on LULC, hydrological soil type, and ground surface condition were first generated using RS and GIS method. These LULC and Soil data were integrated into a GIS environment for intersection which produces a quick and accurate estimation of the runoff curve number for the streams, which is a function of the data acquired via RS.

\subsubsection{Establishment of Gauging Station for Field Measurement of streamflow}

As the last available archival data in Owan sub-basins was recorded in the year 1999, there was need to validate simulated data obtained from using the NRCS-CN model of the United States Department of Agriculture (USDA) with the field measurements from gauging station established along Owan river course in Sabongida where stage height data were collected for a period of 12 months (January to December 2018) and converted to discharge utilizing equation 1 (ISO 1998). In creating the gauging station certain factors such as site accessibility, the security of gauging equipment, flow consistency, etc. were considered. The gauging station monthly average discharge measurements obtained were compared with simulated data obtained using the NRCS-CN method by Pearson's product-moment correlation statistical approach at 0.05 level of confidence to determine the statistical significance of the obtained results.

$$
Q=C(h-a)^{\propto}
$$

Where $\mathrm{Q}=$ discharge, $\mathrm{h}=$ stage height and $\mathrm{C}, \mathrm{a}, \alpha=$ calibration constants. Effective flow depth $(\mathrm{h}-\mathrm{a})=1$ when $\mathrm{C}$ $=$ discharge; $\mathrm{a}=$ zero flow gauge height; $\alpha=$ rating curve slope; (h-a) water effective depth.

\subsection{Estimation of Streamflow for Ungauged Parts of Owan Sub-Basins using NRSC-CN}

Since the CN map has been successfully generated and necessary $C N$ values obtained from the 125 mapped out points at $2 \mathrm{~km}$, the next goal is the computation of maximum potential retention (S) expressed by the relation in (2) (Salimi et al. 2016).

$$
s=\frac{25400}{C N}-254
$$

where $S=$ potential maximum retention (mm); $C N=$ Curve Number.

The depth of runoff $\left(Q_{d}\right)$ was calculated for each rainfall event by using equation (3) (Salimi et al 2016).

$$
Q_{d}=\frac{[P-0.2 S]^{2}}{P+0.8 S}
$$

$Q_{d}=$ runoff depth $(\mathrm{mm}) ; P=$ rainfall $(\mathrm{mm})$ and $S=$ potential maximum retention $(\mathrm{mm})$

Peak discharge $Q_{p}$ for the stream on yearly and monthly bases was calculated using equation (4): Salimi et al, (2016).

$$
Q p=\frac{2.083 * A * Q d}{t p}
$$

$Q_{p}=$ peak runoff rate unit hydrograph $\left(\mathrm{m}^{3} / \mathrm{s}\right)$, and $t_{p}=$ time to peak runoff unit hydrograph $(\mathrm{h})$. The only unknown variable in equation 3 is time to peak $t_{p}$, and this was evaluated using the relationship between time of concentration $t_{c}$ and $t_{p}$. The relationship between $t_{p}$ and $t_{c}$ is given in equation 5 (Roussel et al, 2005);

$$
N R C S t_{p}=0.6 t_{c}
$$

The value of $t_{c}$ was obtained by equation 6 (NRCS 1997; Li, et al 2008):

$$
\mathrm{t}_{\mathrm{c}}=0.0526[(1000 / \mathrm{CN})-9] \mathrm{L}^{0.8} \mathrm{~S}^{-0.5}
$$

where $t_{c}=$ time of concentration $(\mathrm{hr}) ; C N=$ curve number; $L=$ flow length $(\mathrm{ft}) ; S=$ average watershed slope, $(\%)$.

\subsection{Generation of Flow Duration Curve}

A flow duration curve (FDC) is a statistical illustration of the quantity of hydrologically obtainable water and the allocation or characteristics of daily, monthly, or yearly flows. FDC of Owan sub-basin was generated on monthly basis to determine the amount of water available per time in the basin as applied by (Smakhtin 2001; Yu et al, $2002)$ in their research. The probability of exceedance $(P)$ was calculated utilizing relation 7 :

$$
P=\frac{M}{n+1} X 100 \%
$$

$P=$ the probability that a given flow will be equaled or exceeded ( $\%$ of time); $M=$ the ranked position on the listing (dimensionless) $n=$ the number of events for a period of record (dimensionless). The essence of developing the FDC is to assist the selection of a design discharge $(Q o)$ favorable to identified towns and settlements in the sub-basin that will be adopted for calculation of SHP potential of sustainable hydrological points in this study.

\subsection{Hydropower Potential (P) Optimization}

In this study, a total of One hundred and twenty-five (125) points were represented along the main river course and tributaries of Owan sub-basin at $2 \mathrm{~km}$ intervals as presented in Figure 4 using RS and GIS tool. To determine suitable points for hydropower exploitation, optimization benchmarks were set for this study using the sub-basin physiographic indicators (Slope and Available head). The optimization criteria state that for a hydrometric point 
to be considered viable for SHP project it must have a minimum slope and available of $2 \%$ and $10 \mathrm{~m}$ respectively between two ends equal $2 \mathrm{~km}$. The Slope ( $\geq 2 \%$ ) conforms to the standard discussed in (Kusre et al. 2010; Pandey et al. 2015) while the available head was reduced to $10 \mathrm{~m}$ in contrast to $20 \mathrm{~m}$ proposed to accommodate the peculiarity of Owan sub-basin.

On determination of flow exceedance or design discharge $\left(\mathrm{Q}_{0}\right)$ at each town which was adopted as $\mathrm{Q}_{92}$, the Run of River (ROR) hydropower potential was computed using equation 8 (Taulo 2007)

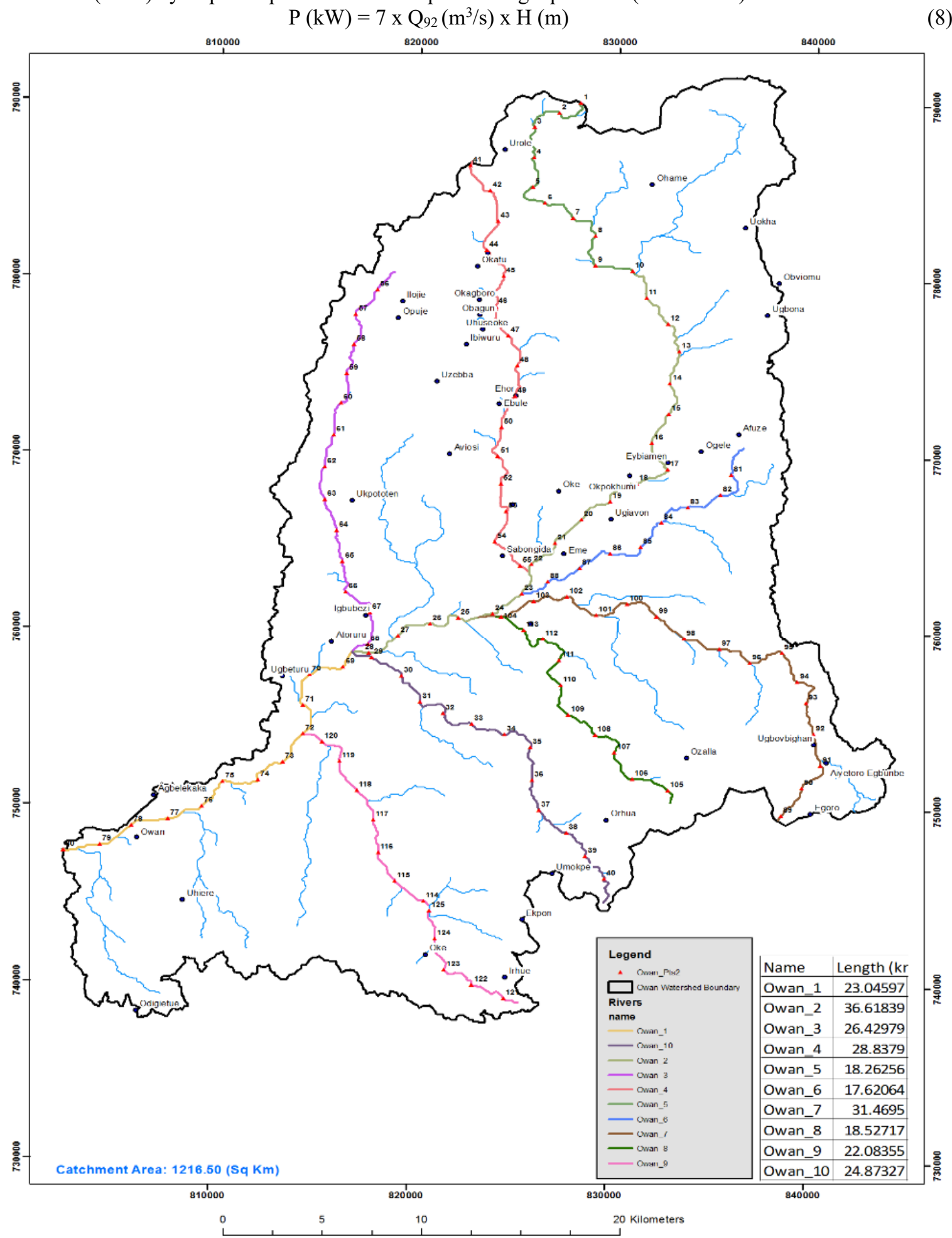

Figure 4: Selected hydropower potential sites in Owan watershed at $2 \mathrm{~km}$ points. 


\subsection{Results \& Discussions}

\subsection{Owan Catchment Characteristics}

The basic objective of verifying Owan catchment physiographic is to have an in-depth understanding of the watershed for the purpose of maximizing its hydrological and power potential. This was carried out by generating the necessary study maps such as DEM (Figure 5), Rainfall (Figure 6), Slope (Figure 7), Soil (Figure 8), LULC (Figure 9), CN (Figure 10) with the aid of RS and GIS procedures.

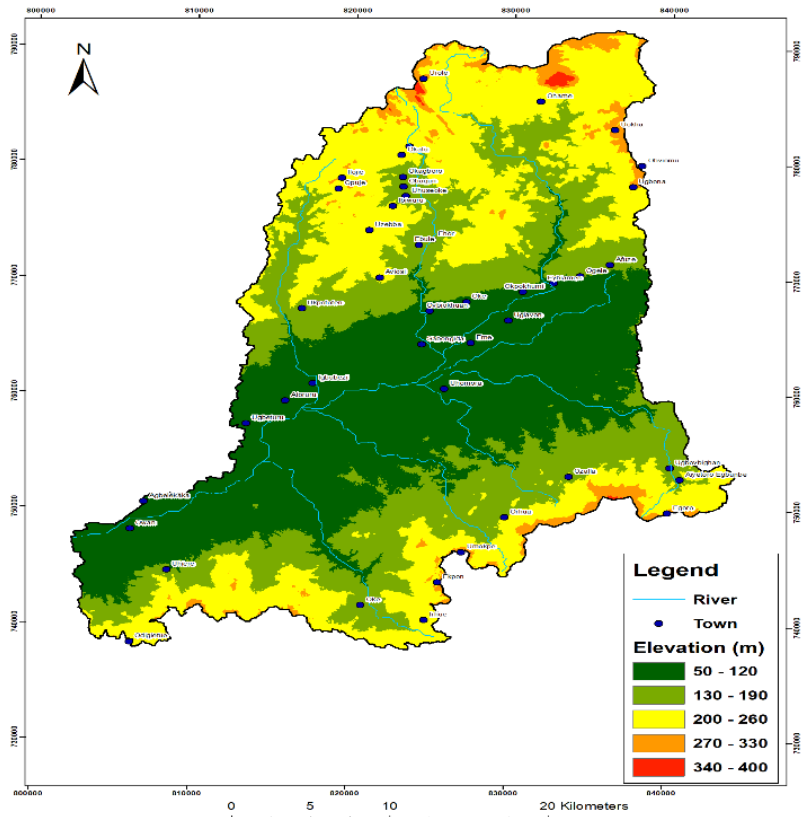

Figure 5: Owan DEM Map

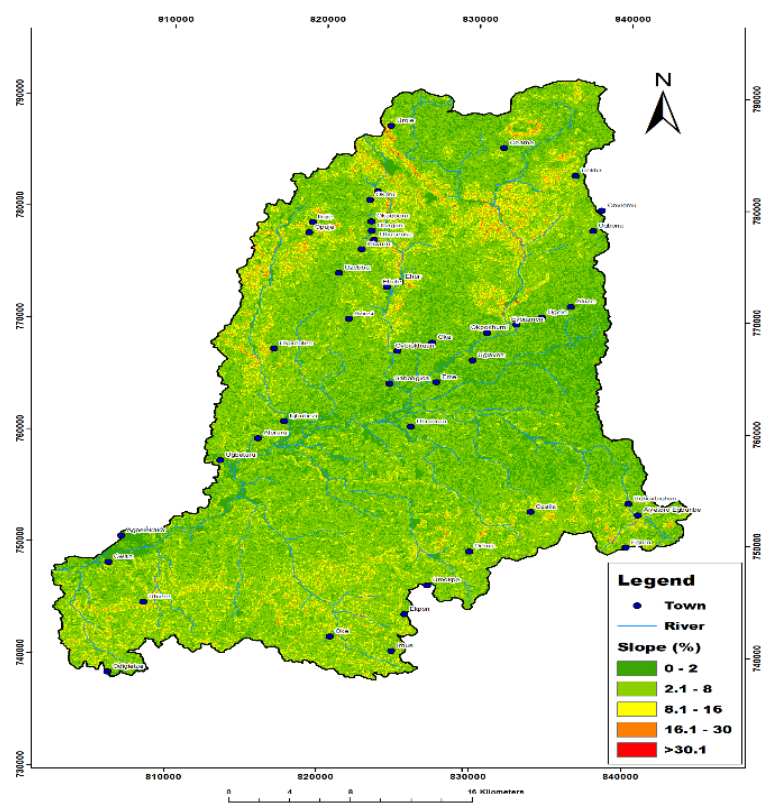

Figure 7: Owan Slope Map

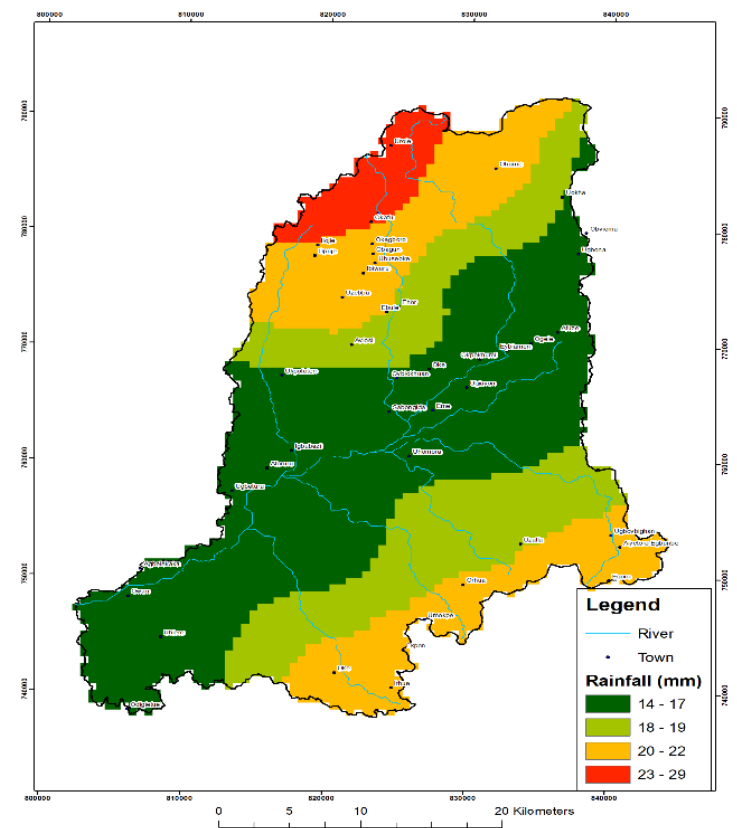

Figure 6: Owan Rainfall Map

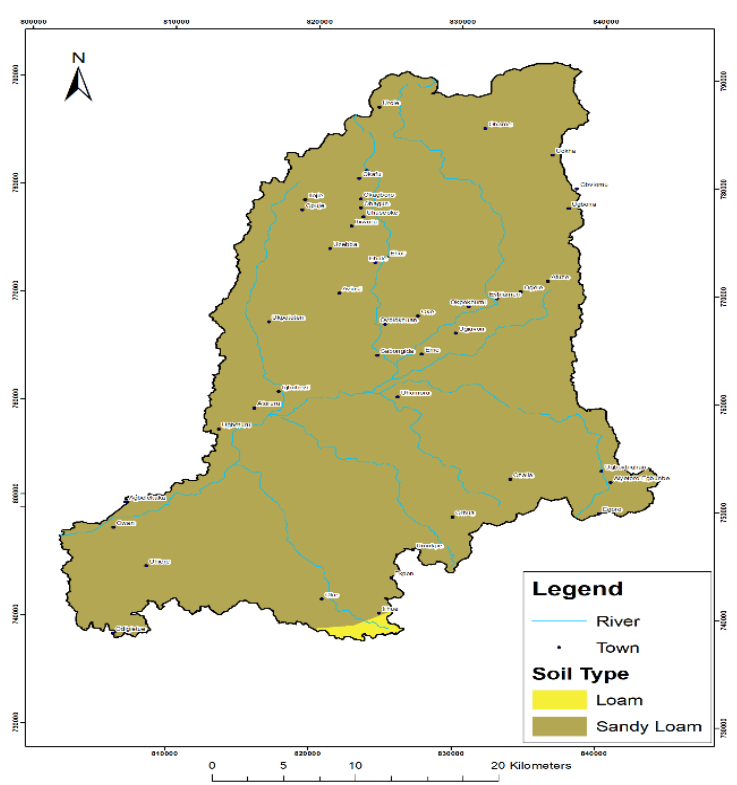

Figure 8: Owan Soil Map 


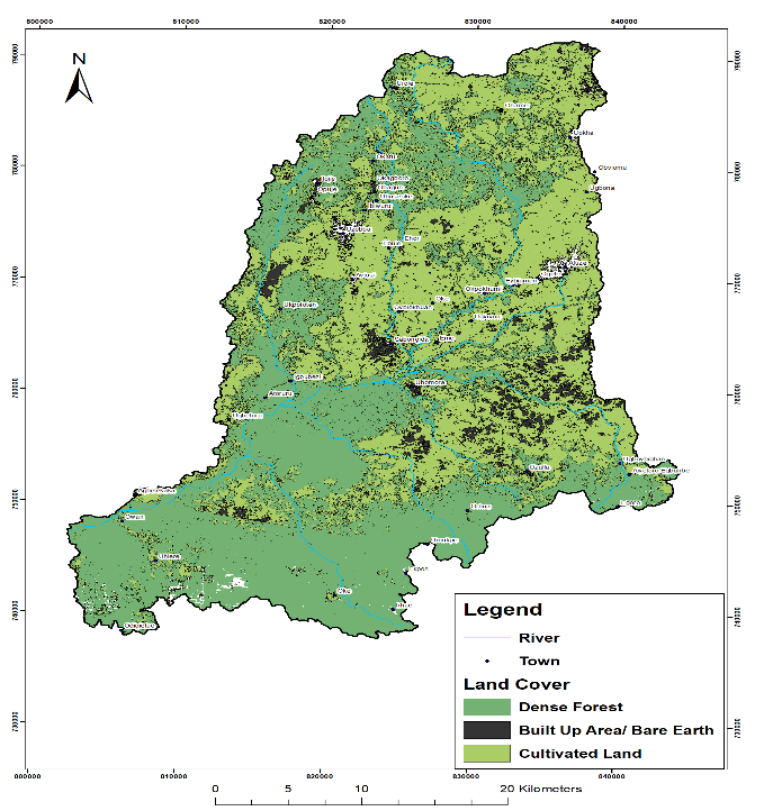

Figure 9: Owan LULC Map

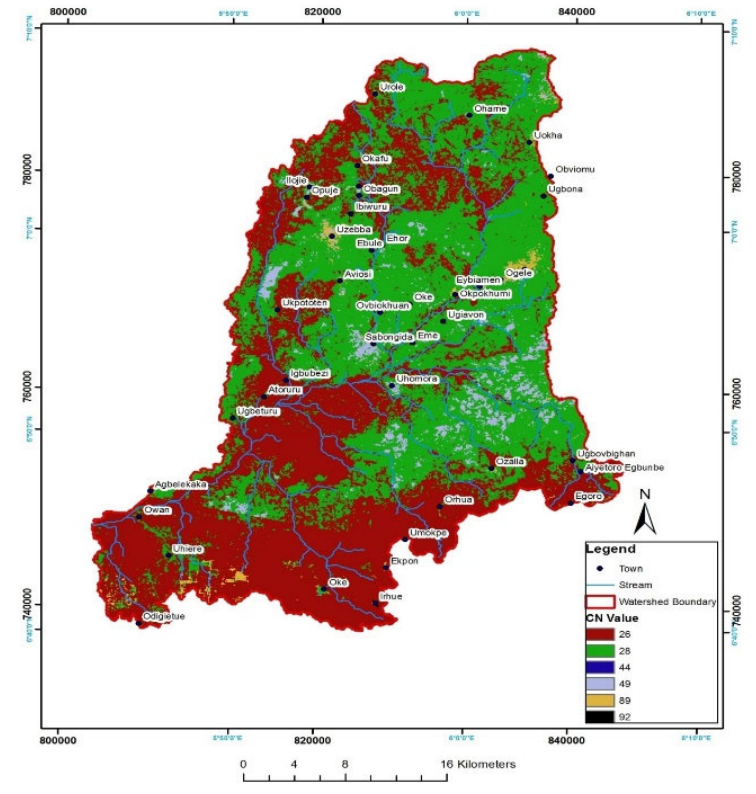

Figure 10: Owan CN Map

In SHP potential investigation, one of the regular variables to consider is the available head/falling height of the river which was obtained from Figure 5 by calculating the change in elevation between two points of interest. The DEM of Owan sub-basin ranges between 50-400 m and this implies adequate hydraulic head exist for SHP scheme development.

The rainfall map (Figure 6) was developed to obtain temporal and spatial precipitation allocation over the catchment which is critical in hydrological interpretation and substantiation (Douglas et al. 2008). The obtained rainfall distribution in the watershed is $14.40 \mathrm{~mm}$ to $28.90 \mathrm{~mm}$ categorized as moderate rain and moderately heavy rain (Mannan et al. 2008).

The slope indicates the resultant SHP potential of any scheme. The identified slope discovered in Owan watershed varies between $0-42.7 \%$. From Figure 7, the slope was grouped based on existence into five (5) relief sizes namely Plane (0-2 \%), Undulating (2.1-8 \%), Gently sloping (8.1-16\%), Strongly sloping (16.1-30\%) and Highly Steep ( $>30.1 \%$ ) terrains (Vemu et al. 2010). This was further utilized in computing time of concentration.

Owan soil map (Figure 8) was developed to identify the soil texture present in the catchment with a view of categorizing it into Hydrological Soil Groups (HSGs) based on the USDA classification. The identified soil texture (IST) in Owan sub-basin are sandy-loam and loam which belong to the Hydrological soil group (HSG) family of A and B respectively (Viji et al. 2015). The RS obtained IST is in good agreement with field investigation.

Supervised image classification was performed on Landsat 8 satellite imagery within the ArcGIS environment using the Image Analysis tool, to generate the LULC map of Owan watershed. The watershed map produces three (3) LULC categories i.e., dense forest, built-up/bare earth, and cultivated land (Figure 9).

The $\mathrm{CN}$ is a derivative of land use and HSG. Therefore, the intersection of LULC and HSG maps was carried out in ArcGIS environment for the purpose of obtaining the $\mathrm{CN}$ map (Figure 10) where accurate $\mathrm{CN}$ values were extracted for use in calculating potential maximum retention in the sub-basin and time of concentration. $\mathrm{CN}$ values fluctuate between 0 and 100. Small $\mathrm{CN}$ values result in high infiltration and low runoff capabilities while large $\mathrm{CN}$ values suggest low infiltration and high runoff. The runoff potentiality of Owan is still poor considering $\mathrm{CN}$ values between $26-28$ constitute $95.51 \%$ of the basin.

Table 1 shows the breakdown of identified Owan catchment parameters, class sizes, the area covered, and percentages obtained by the application of RS and GIS techniques. 
Table 1: Owan Catchment characteristic Parameters

\begin{tabular}{|c|c|c|c|c|}
\hline $\mathrm{S} / \mathrm{N}$ & PARAMETERS & CLASS SIZES & AREA COVERED $\left(\mathrm{M}^{2}\right)$ & PERCENTAGE (\%) \\
\hline \multirow[t]{5}{*}{1.} & \multirow[t]{5}{*}{ DEM } & $50-120$ & 258658200 & 22.59953 \\
\hline & & $130-190$ & 269534700 & 23.54983 \\
\hline & & $200-260$ & 217606500 & 19.01275 \\
\hline & & $270-330$ & 246900600 & 21.57224 \\
\hline & & $340-400$ & 151829100 & 13.26564 \\
\hline \multirow[t]{4}{*}{2.} & \multirow[t]{4}{*}{ RAINFALL } & $14.00-17.00$ & 545297400 & 47.408 \\
\hline & & $18.00-19.00$ & 284127300 & 24.702 \\
\hline & & $20.00-22.00$ & 263886300 & 22.942 \\
\hline & & $23.00-29.00$ & 56903400 & 4.947 \\
\hline \multirow[t]{5}{*}{3.} & \multirow[t]{5}{*}{ Slope } & $0-2 \%$ & 192918600 & 16.86 \\
\hline & & $2.1-8 \%$ & 611336700 & 53.41 \\
\hline & & $8.1-16 \%$ & 261778500 & 22.87 \\
\hline & & $16.1-30 \%$ & 70011000 & 6.12 \\
\hline & & $>30.1 \%$ & 8483400 & 0.74 \\
\hline \multirow[t]{4}{*}{4.} & $\begin{array}{c}\text { Identified Soil } \\
\text { Texture }\end{array}$ & \multicolumn{3}{|c|}{ Hydrologic Soil Group } \\
\hline & & $\mathrm{A}$ & $\mathrm{C}$ & $\mathrm{D}$ \\
\hline & Sandy Loam & $\checkmark$ & & \\
\hline & Loam & & $\checkmark$ & \\
\hline \multirow[t]{3}{*}{5.} & \multirow[t]{3}{*}{ LULC } & Mixed Veg & 595960041 & 49.53 \\
\hline & & Dense Veg & 553206204 & 45.98 \\
\hline & & BU/Bare Earth & 53993104 & 4.49 \\
\hline \multirow[t]{5}{*}{6.} & \multirow[t]{5}{*}{$\mathrm{CN}$} & 26 & 559489500 & 45.98 \\
\hline & & 28 & 603845100 & 49.63 \\
\hline & & 49 & 39888000 & 3.28 \\
\hline & & 89 & 13436100 & 1.10 \\
\hline & & 92 & 102600 & 0.01 \\
\hline
\end{tabular}

\subsection{Rainfall Correlation}

The validation was carried out for monthly precipitation and the analysis was based on a statistical approach using Pearson's Product Moment Correlation statistics between NIMET and PERSIANN datasets for towns in Owan sub-basin. On the Average, Owan Sub-basin indicates spatial correlation coefficients of 0.70 (Table 2) to show that the PERSIANN-CDR data are reliable with highly significant dependability status (Travers et al. 2017).

Table 2: Result of Correlation between NIMET and PERSIANN Rainfall data set for Owan Sub-basin

\begin{tabular}{|c|c|c|c|c|c|c|}
\hline Town & Multiple R & $\mathbf{R}^{\mathbf{2}}$ & Adjusted R $^{\mathbf{2}}$ & P-value & Statistical relevance & Remark \\
\hline Urole & 0.83519 & 0.697543 & 0.667297 & 0.00072 & Highly significant & Accepted \\
\hline Eybiamen & 0.827032 & 0.683981 & 0.652379 & 0.00090 & Highly significant & Accepted \\
\hline Eme & 0.829629 & 0.688285 & 0.657113 & 0.00084 & Highly significant & Accepted \\
\hline Uhomora & 0.834138 & 0.695787 & 0.665366 & 0.00074 & Highly significant & Accepted \\
\hline Umokpe & 0.831864 & 0.691997 & 0.661197 & 0.00079 & Highly significant & Accepted \\
\hline Ehor & 0.838442 & 0.702984 & 0.673283 & 0.00066 & Highly significant & Accepted \\
\hline Sabongida & 0.836126 & 0.699107 & 0.669018 & 0.00070 & Highly significant & Accepted \\
\hline Opuje & 0.844274 & 0.712798 & 0.684078 & 0.00055 & Highly significant & Accepted \\
\hline Igubezi & 0.839988 & 0.705579 & 0.676137 & 0.00063 & Highly significant & Accepted \\
\hline Ugbeturu & 0.839197 & 0.704251 & 0.674676 & 0.00064 & Highly significant & Accepted \\
\hline Owan & 0.846558 & 0.71666 & 0.688326 & 0.00051 & Highly significant & Accepted \\
\hline Afuze & 0.827254 & 0.68435 & 0.652785 & 0.00090 & Highly significant & Accepted \\
\hline Egoro & 0.818605 & 0.670114 & 0.637125 & 0.00113 & Highly significant & Accepted \\
\hline Ozalla & 0.825081 & 0.680759 & 0.648834 & 0.00095 & Highly significant & Accepted \\
\hline Oke & 0.836467 & 0.699676 & 0.669644 & 0.0007 & Highly significant & Accepted \\
\hline Irhue & 0.837508 & 0.70142 & 0.671563 & 0.00067 & Highly significant & Accepted \\
\hline
\end{tabular}

\subsection{Discharge Correlation between Observed and Estimated}

A $68 \%$ correlation was registered at Owan sub-basins which proves the NRCS-CN model can successfully simulate runoff for poorly gauged or ungauged basins. The results as presented in Table 3 show that the GIS and 
RS basin parameters determined from satellite images such as LULC help examine the runoff response of ungauged basins. The study reveals that there is a complementarity between measured and estimated runoff. The correlation results of estimated discharge across Owan sub-basins are reasonably acceptable; considering statistical tests and p-values as outlined by (Travels et al. 2017) that P-values $\geq 0.05$ (not significant), $<0.05$ (significant), $<$ 0.02 (highly significant).

Table 3: Result of Correlation between Measured and Estimated Discharge data set for Owan Sub-basin

\begin{tabular}{|c|c|c|c|c|c|c|c|}
\hline Town & Equation & $\begin{array}{l}\text { Multiple } \\
\text { R }\end{array}$ & $\mathbf{R}^{2}$ & $\begin{array}{l}\text { Adjusted } \\
\mathbf{R}^{2}\end{array}$ & P-value & $\begin{array}{l}\text { Statistical } \\
\text { relevance }\end{array}$ & Remark \\
\hline Urole & \multirow{16}{*}{  } & 0.818394 & 0.669769 & 0.636746 & 0.00114 & Highly significant & Accepted \\
\hline Eybiamen & & 0.812576 & 0.660279 & 0.626307 & 0.00132 & Highly significant & Accepted \\
\hline Eme & & 0.815745 & 0.66544 & 0.631984 & 0.00122 & Highly significant & Accepted \\
\hline Uhomora & & 0.825961 & 0.682211 & 0.650432 & 0.00093 & Highly significant & Accepted \\
\hline Umokpe & & 0.824883 & 0.680433 & 0.648476 & 0.00096 & Highly significant & Accepted \\
\hline Ehor & & 0.824666 & 0.680074 & 0.648081 & 0.00096 & Highly significant & Accepted \\
\hline Sabongida & & 0.826373 & 0.682892 & 0.651181 & 0.00092 & Highly significant & Accepted \\
\hline Opuje & & 0.832809 & 0.693571 & 0.662928 & 0.00077 & Highly significant & Accepted \\
\hline Igubezi & & 0.834841 & 0.69696 & 0.666656 & 0.00073 & Highly significant & Accepted \\
\hline Ugbeturu & & 0.836622 & 0.699936 & 0.66993 & 0.00069 & Highly significant & Accepted \\
\hline Owan & & 0.846472 & 0.716515 & 0.688167 & 0.00052 & Highly significant & Accepted \\
\hline Afuze & & 0.818437 & 0.669839 & 0.636823 & 0.00114 & Highly significant & Accepted \\
\hline Egoro & & 0.810855 & 0.657485 & 0.623234 & 0.00137 & Highly significant & Accepted \\
\hline Ozalla & & 0.81764 & 0.668535 & 0.635388 & 0.00116 & Highly significant & Accepted \\
\hline Oke & & 0.831781 & 0.691859 & 0.661045 & 0.00079 & Highly significant & Accepted \\
\hline Irhue & & 0.828524 & 0.686451 & 0.655096 & 0.00087 & Highly significant & Accepted \\
\hline
\end{tabular}

\subsection{Discharge Descriptive Statistics Across Owan Catchment}

The discharge descriptive statistics across towns in Owan is presented in Table 4.

Table 4: Descriptive Statistics for Discharge in Owan Catchment

\begin{tabular}{|c|c|c|c|c|c|c|c|}
\hline TOWN & Mean & SD & Variance & Range & Minimum & Maximum & Sum \\
\hline Measured & 3298.422 & 3650.352 & 13325070.412 & 11488.454 & 15.561 & 11504.015 & 39581.063 \\
\hline Urole & 2703.224 & 2705.991 & 7322388.341 & 7908.061 & 1.558 & 7909.619 & 32438.69 \\
\hline Eybiamen & 2662.744 & 2716.224 & 7377871.779 & 8049.800 & 2.203 & 8052.003 & 31952.923 \\
\hline Eme & 406.590 & 419.167 & 175701.320 & 1261.660 & 0.170 & 1261.831 & 4879.078 \\
\hline Uhomora & 3807.451 & 3886.494 & 15104832.065 & 11734.741 & 2.175 & 11736.916 & 45689.410 \\
\hline Umokpe & 15272.753 & 15488.504 & 239893751.378 & 47225.071 & 6.991 & 47232.062 & 183273.034 \\
\hline Ehor & 10855.008 & 10655.394 & 113537431.579 & 31313.446 & 13.359 & 31326.805 & 130260.095 \\
\hline Sabongida & 2951.661 & 2967.188 & 8804205.742 & 8807.393 & 1.706 & 8809.098 & 35419.931 \\
\hline Opuje & 7354.844 & 7128.337 & 50813185.359 & 21089.914 & 10.001 & 21099.916 & 88258.131 \\
\hline Igubezi & 4278.149 & 4284.424 & 18356291.127 & 12813.864 & 3.379 & 12817.242 & 51337.786 \\
\hline Ugbeturu & 702.493 & 707.785 & 500959.497 & 2139.296 & 0.576 & 2139.872 & 8429.917 \\
\hline Owan & 1288.029 & 1274.924 & 1625430.669 & 3857.134 & 1.001 & 3858.135 & 15456.345 \\
\hline Afuze & 10957.095 & 11251.428 & 126594636.643 & 33866.259 & 4.574 & 33870.834 & 131485.143 \\
\hline Egoro & 8346.926 & 8616.693 & 74247403.364 & 26168.084 & 5.957 & 26174.041 & 100163.106 \\
\hline Ozalla & 4634.274 & 4746.998 & 22533985.776 & 14470.773 & 2.720 & 14473.492 & 55611.285 \\
\hline Oke & 9508.391 & 9558.595 & 91366733.508 & 29242.811 & 6.320 & 29249.131 & 114100.687 \\
\hline Irhue & 8055.525 & 7989.029 & 63824589.596 & 24508.784 & 0.925 & 24509.709 & 96666.295 \\
\hline
\end{tabular}

To ascertain the quantity of water available for energy generation activities and flow seasonality of Owan catchment, the available discharge potential was evaluated. From Table 4, the standard deviation (SD) which shows the degree of convergence of the data around the mean indicates a normal distribution $(\mu+\sigma)$ for Owan catchment because the values across all the examined towns are within one SD which is $68 \%$ where $\mu \& \sigma$ denote mean \& standard deviation correspondingly (Czitrom et al. 1997; Pukelsheim 1994). The maximum and minimum monthly average discharge values are 15,272.753 and 406.590 obtained in Umokpe and Eme respectively. Umokpe registered the greatest annual discharge of $183273.034 \mathrm{~m}^{3} / \mathrm{s}$ with minimum and maximum estimated values of $15.561 \mathrm{~m}^{3} / \mathrm{s}$ and $47,232.062 \mathrm{~m}^{3} / \mathrm{s}$ respectively. Comparing the estimated discharge values with the last set of archival values obtained in 1999 for Owan, (BORBDA 2007), there is a rise in runoff owing to LULC.

\subsection{Rainfall Hyetograph - Runoff Hydrograph for Owan Catchment}

Figure 11 to 26 describes the monthly analysis of rainfall and discharge behaviors across townships of Owan catchment in year 2018. The hyetograph and hydrograph illustrate more time is need for them to peak as indicated 
by the growing limb compare to diminishing limb from the January to December successiveness consider for analysis. Rainfall configuration significantly influences runoff hydrograph (Sraj et al. 2010) as observed in the Figures below. This clearly presents the importance of precipitation data in the NRCS-CN method.

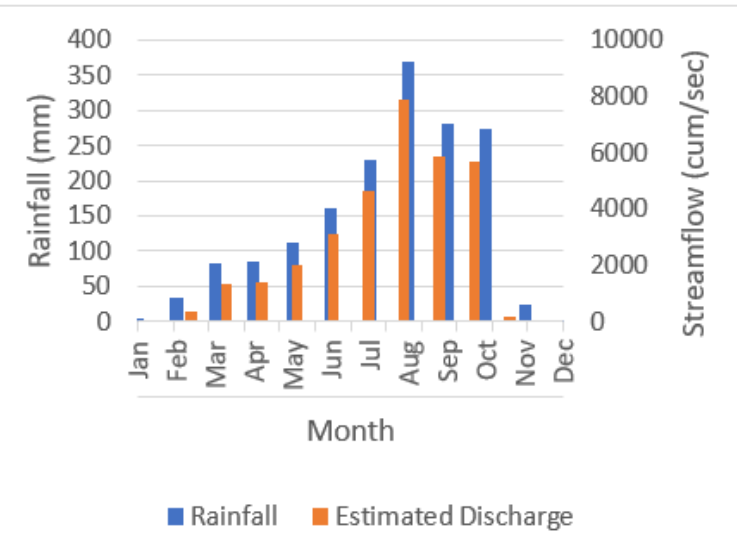

Figure 11: Urole Rainfall hyetograph-runoff hydrograph

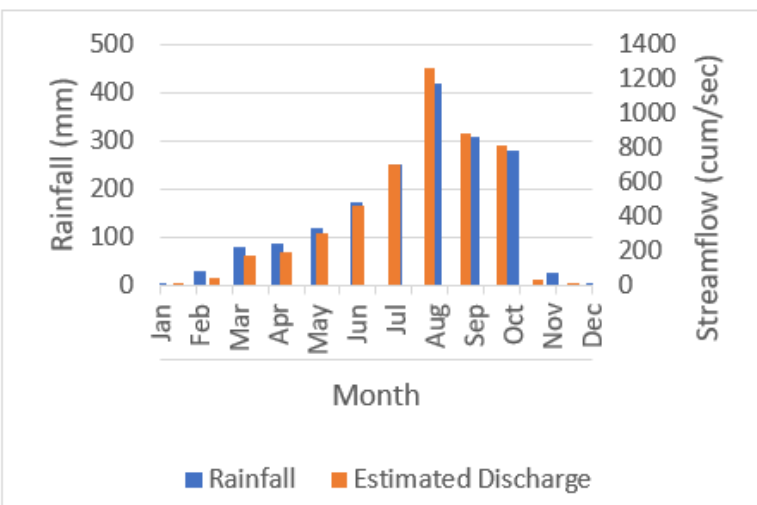

Figure 13: Eme Rainfall hyetograph-runoff hydrograph

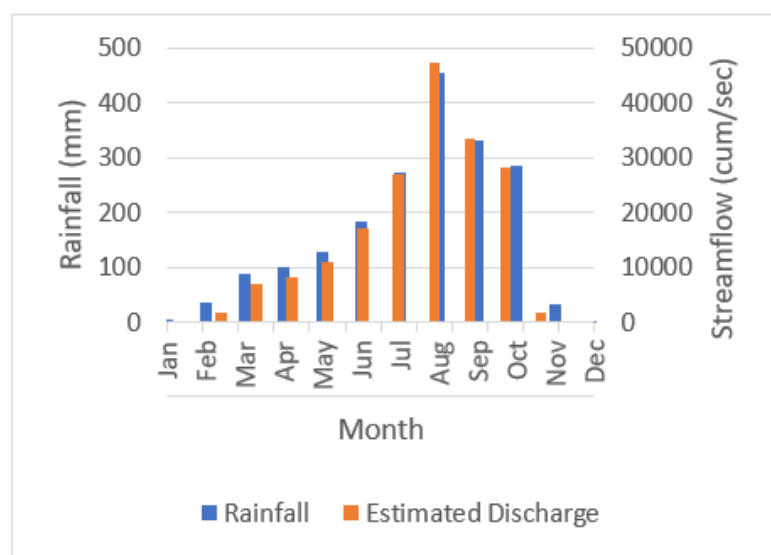

Figure 15: Umokpe Rainfall hyetograph-runoff hydrograph

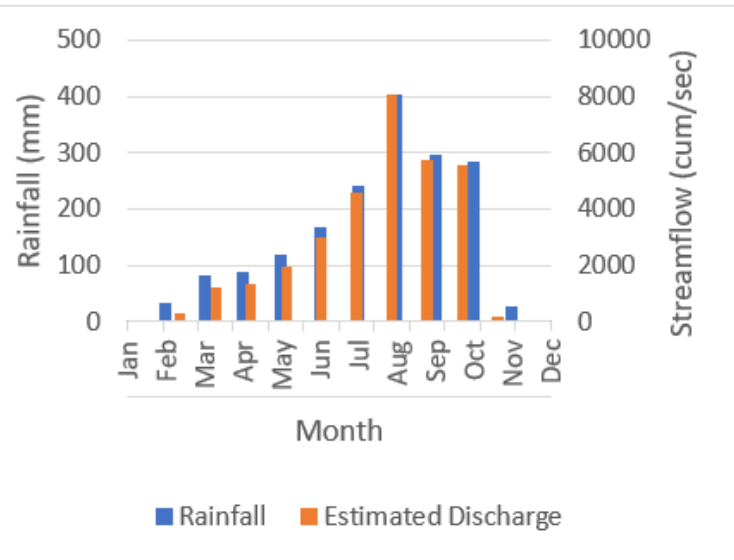

Figure 12: Eybiamen Rainfall hyetograph-runoff hydrograph



Figure 14: Uhomora Rainfall hyetograph-runoff hydrograph

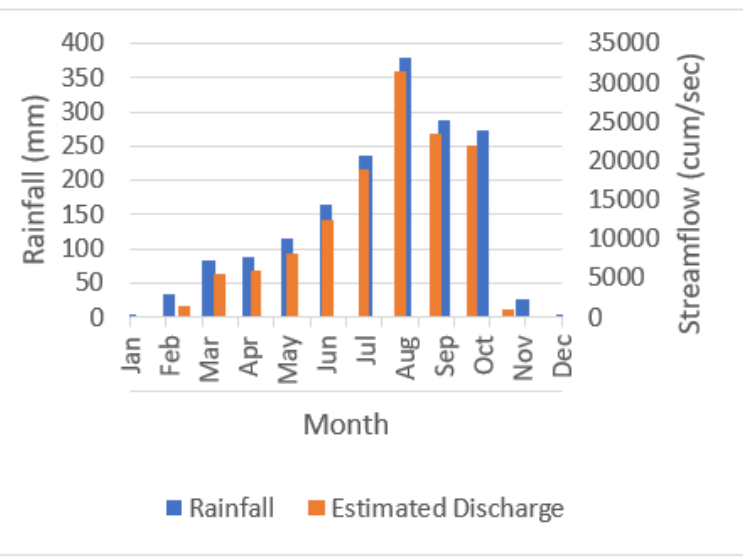

Figure 16: Ehor Rainfall hyetograph-runoff hydrograph 


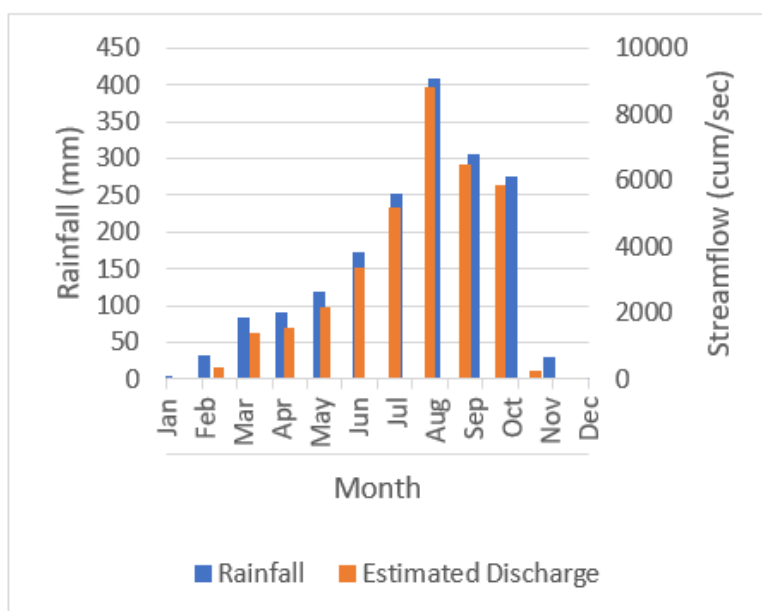

Figure 17: Sabongida Rainfall hyetograph-runoff hydrograph



Figure 19: Igubezi Rainfall hyetograph-runoff hydrograph

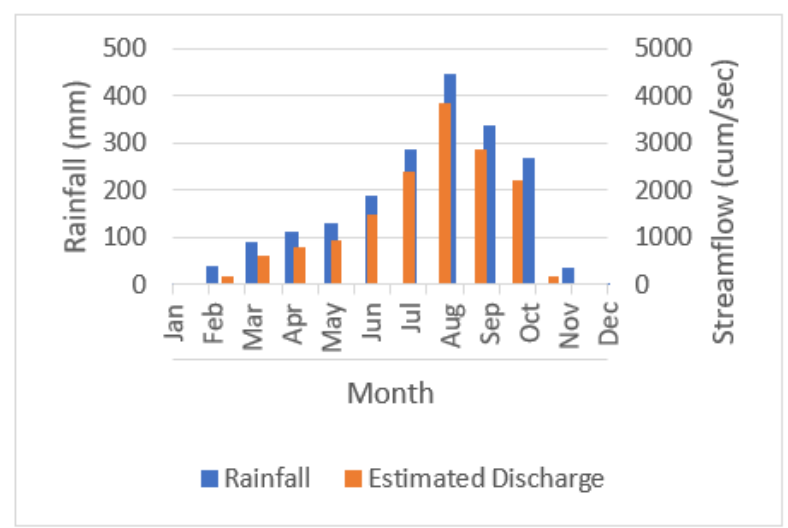

Figure 21: Owan Rainfall hyetograph-runoff hydrograph



Figure18: Opuje Rainfall hyetograph-runoff hydrograph

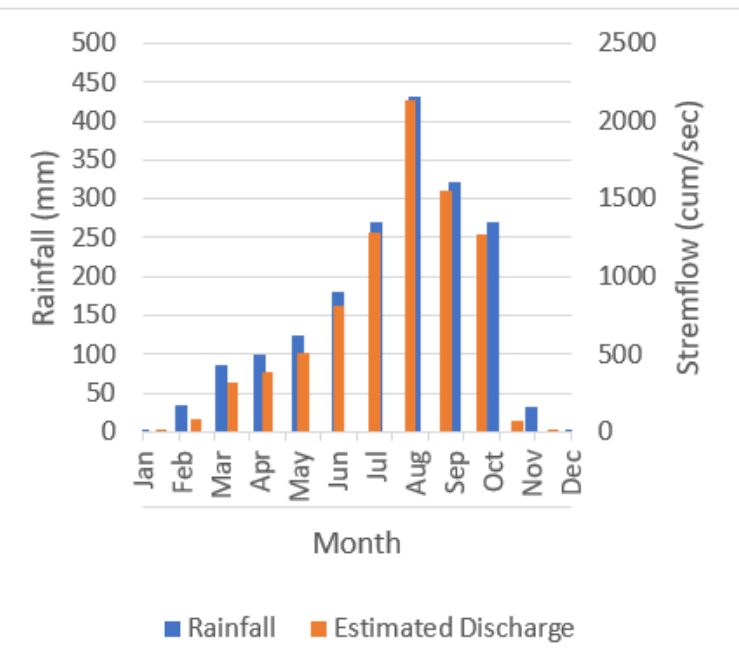

Figure 20: Ugbeturu Rainfall hyetograph-runoff hydrograph



Figure 22 Afuze Rainfall hyetograph-runoff hydrograph 


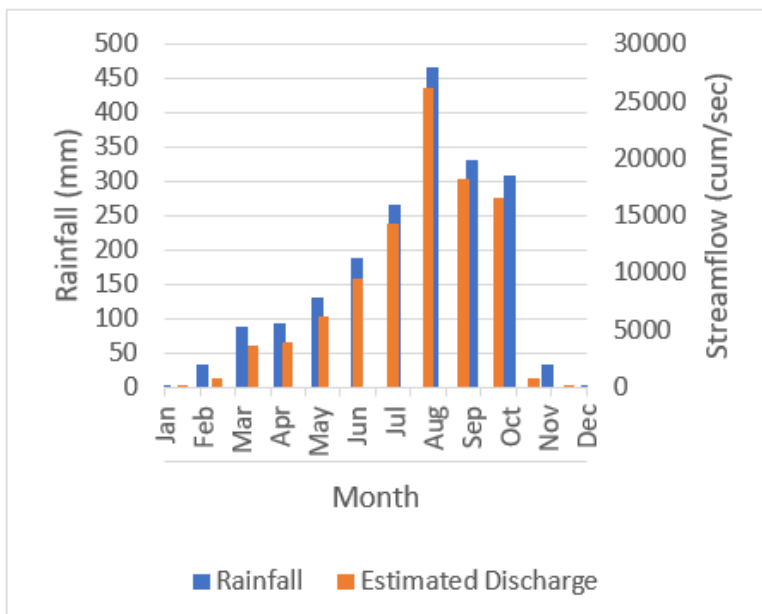

Figure 23: Egoro Rainfall hyetograph-runoff hydrograph

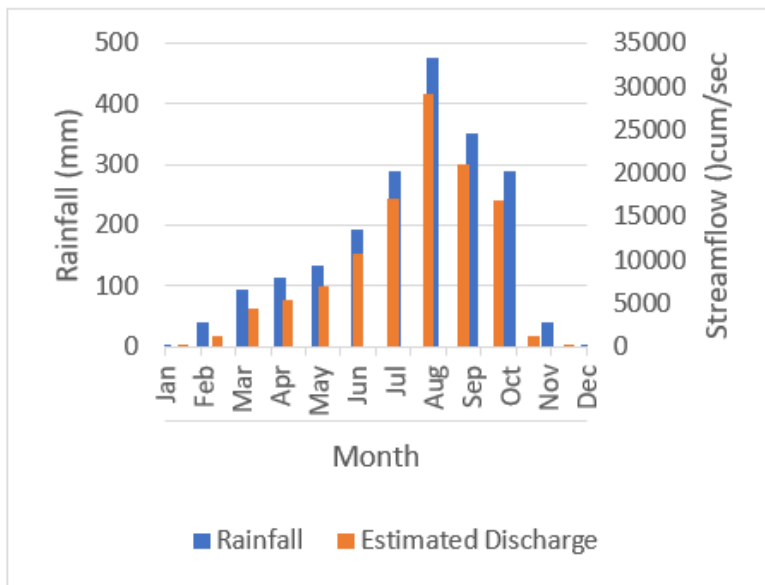

Figure 25: Oke Rainfall hyetograph-runoff hydrograph

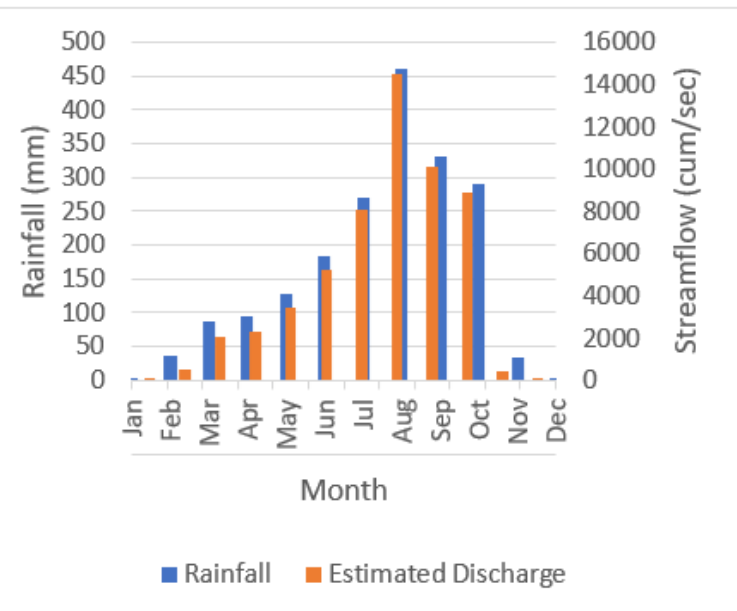

Figure 24: Ozalla Rainfall hyetograph-runoff hydrograph

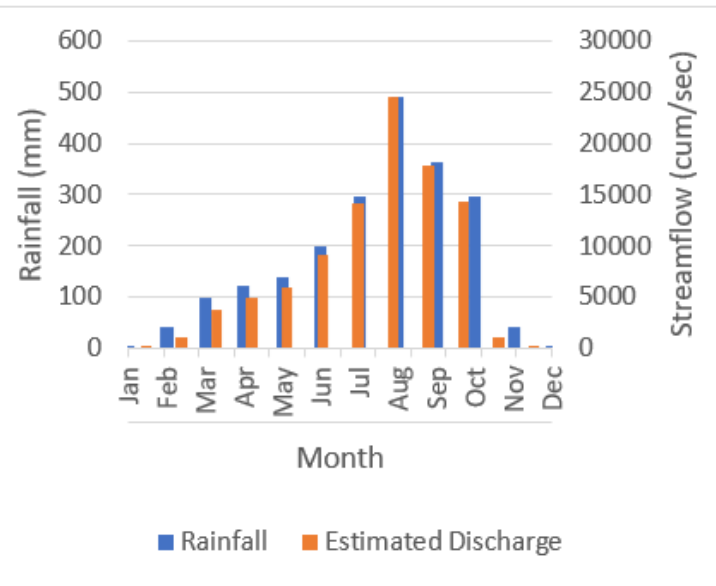

Figure 26: Irhue Rainfall hyetograph-runoff hydrograph

3.6 FDC Analysis for Towns in Owan Sub-basin.

From the developed FDC of Owan catchment for a period of twelve months, flows which are equaled or exceeded at $8 \%, 17 \%, 25 \%, 33 \%, 42 \%, 50 \%, 58 \%, 67 \%, 75 \%, 83 \%, 92 \%$ and $100 \%$ were obtained. (Sahu 2015 ; MNRE 2008) utilized $75 \%$ and $90 \%$ exceedance values respectively in their studies while this research adopts $92 \%$ exceedance probability. Table 5 shows the obtainable discharge equaled or exceeded at $92 \%$ of the time utilized for hydropower potential estimations across viable points in Owan watershed. 
Table 5: FDC Q92 for Towns in Owan Sub-basin

\begin{tabular}{|c|c|}
\hline Town & Q $_{92}$ Flow equaled or Exceeded $\left(\mathrm{m}^{3} / \mathrm{s}\right)$ \\
\hline Urole & 5.035888 \\
\hline Eybiamen & 5.941597 \\
\hline Eme & 1.402623 \\
\hline Uhomora & 10.48928 \\
\hline Umokpe & 28.42356 \\
\hline Ehor & 16.16917 \\
\hline Sabongida & 5.328053 \\
\hline Opuje & 10.98024 \\
\hline Igubezi & 9.116655 \\
\hline Ugbeturu & 1.513738 \\
\hline Owan & 1.809837 \\
\hline Afuze & 33.10717 \\
\hline Egoro & 32.48003 \\
\hline Ozalla & 10.1014 \\
\hline Oke & 17.17374 \\
\hline Irhue & 5.732755 \\
\hline
\end{tabular}

\subsection{Owan SHP Potential}

Having established a strong relationship between the rainfall and discharges in the Owan catchment, this study recommended the use of the $\mathrm{Q}_{92}$ flow statistic obtained from the FDC of relevant towns close to the potential point as listed in Table 5. Reflecting the catchment optimization criteria as defined for this study to identify viable points which are $2 \%$ minimum slope (slope $\geq 2 \%$ ) (Kusre et al. 2010; Pandey et al. 2015) and minimum $10 \mathrm{~m}$ available head $(\mathrm{H} \geq 10 \mathrm{~m}), 20$ potential sites as represented in Figure 27 were discovered in Owan sub-basin and the locations/point number along the river network are shown in Table 6. This gives rise to the determination of SHP potential using equation 8 .

Table 6 Hydropower Potential and Turbine Choice for Owan Sub-Basin

\begin{tabular}{|l|c|c|c|c|c|c|c|c|}
\hline $\mathbf{S} / \mathbf{N}$ & Town & Points & X-Cord & Y-Cord & $\begin{array}{c}\text { Slope } \\
\mathbf{( \% )}\end{array}$ & $\begin{array}{c}\text { Available } \\
\text { Head (m) }\end{array}$ & $\begin{array}{c}\text { Discharge } \\
\mathbf{Q}_{\mathbf{9}}\left(\mathbf{m}^{\mathbf{3}} \mathbf{/ s} \mathbf{)}\right.\end{array}$ & $\begin{array}{c}\text { Power } \\
\text { Potential } \\
\mathbf{( k W )} \\
\mathbf{/ Y e a r}\end{array}$ \\
\hline $\mathbf{1 .}$ & Urole & 8 & 828875.742 & 782483.273 & 3.07759 & 12.000 & 5.036 & 423.015 \\
\hline $\mathbf{2 .}$ & Eybiamen & 11 & 831506.564 & 778991.701 & 3.65935 & 13.000 & 5.942 & 540.685 \\
\hline $\mathbf{3 .}$ & Eybiamen & 12 & 832607.667 & 777528.317 & 10.91840 & 12.000 & 5.942 & 499.094 \\
\hline $\mathbf{4 .}$ & Umokpe & 32 & 821533.300 & 755302.058 & 4.91619 & 16.000 & 28.424 & 3183.439 \\
\hline $\mathbf{5 .}$ & Umokpe & 33 & 823001.333 & 754724.140 & 2.06055 & 13.000 & 28.424 & 2586.544 \\
\hline $\mathbf{6 .}$ & Umokpe & 37 & 826442.758 & 749877.418 & 5.39147 & 12.000 & 28.424 & 2387.579 \\
\hline $\mathbf{7 .}$ & Umokpe & 38 & 827827.611 & 748623.690 & 3.83370 & 27.000 & 28.424 & 5372.053 \\
\hline $\mathbf{8 .}$ & Umokpe & 39 & 828802.631 & 747293.556 & 7.62469 & 54.000 & 28.424 & 10744.106 \\
\hline $\mathbf{9 .}$ & Ehor & 44 & 823412.618 & 781614.983 & 5.65751 & 33.000 & 16.169 & 3735.077 \\
\hline $\mathbf{1 0 .}$ & Ehor & 45 & 824297.750 & 780152.374 & 5.74345 & 14.000 & 16.169 & 1584.578 \\
\hline $\mathbf{1 1 .}$ & Opuje & 57 & 816872.689 & 777901.439 & 2.55580 & 10.000 & 10.980 & 768.617 \\
\hline $\mathbf{1 2 .}$ & Opuje & 60 & 816189.808 & 772885.547 & 2.35633 & 14.000 & 10.980 & 1076.063 \\
\hline $\mathbf{1 3 .}$ & Egoro & 91 & 840591.448 & 752545.288 & 11.38700 & 24.000 & 32.480 & 5456.646 \\
\hline $\mathbf{1 4 .}$ & Egoro & 92 & 840213.220 & 754344.072 & 3.33236 & 20.000 & 32.480 & 4547.205 \\
\hline $\mathbf{1 5 .}$ & Egoro & 94 & 839375.294 & 757281.645 & 2.35633 & 11.000 & 32.480 & 2500.963 \\
\hline $\mathbf{1 6 .}$ & Oke & 116 & 818369.515 & 747414.069 & 4.91619 & 12.000 & 17.174 & 1442.594 \\
\hline $\mathbf{1 7 .}$ & Irhue & 122 & 823162.378 & 739967.165 & 4.35238 & 52.000 & 5.733 & 2086.723 \\
\hline $\mathbf{1 8 .}$ & Irhue & 123 & 821761.758 & 740792.431 & 9.73221 & 23.000 & 5.733 & 922.974 \\
\hline $\mathbf{1 9 .}$ & Irhue & 124 & 821274.709 & 742550.178 & 3.23286 & 16.000 & 5.733 & 642.069 \\
\hline $\mathbf{2 0 .}$ & Oke & 125 & 820976.768 & 744147.165 & 2.35633 & 16.000 & 17.174 & 1923.459 \\
\hline
\end{tabular}




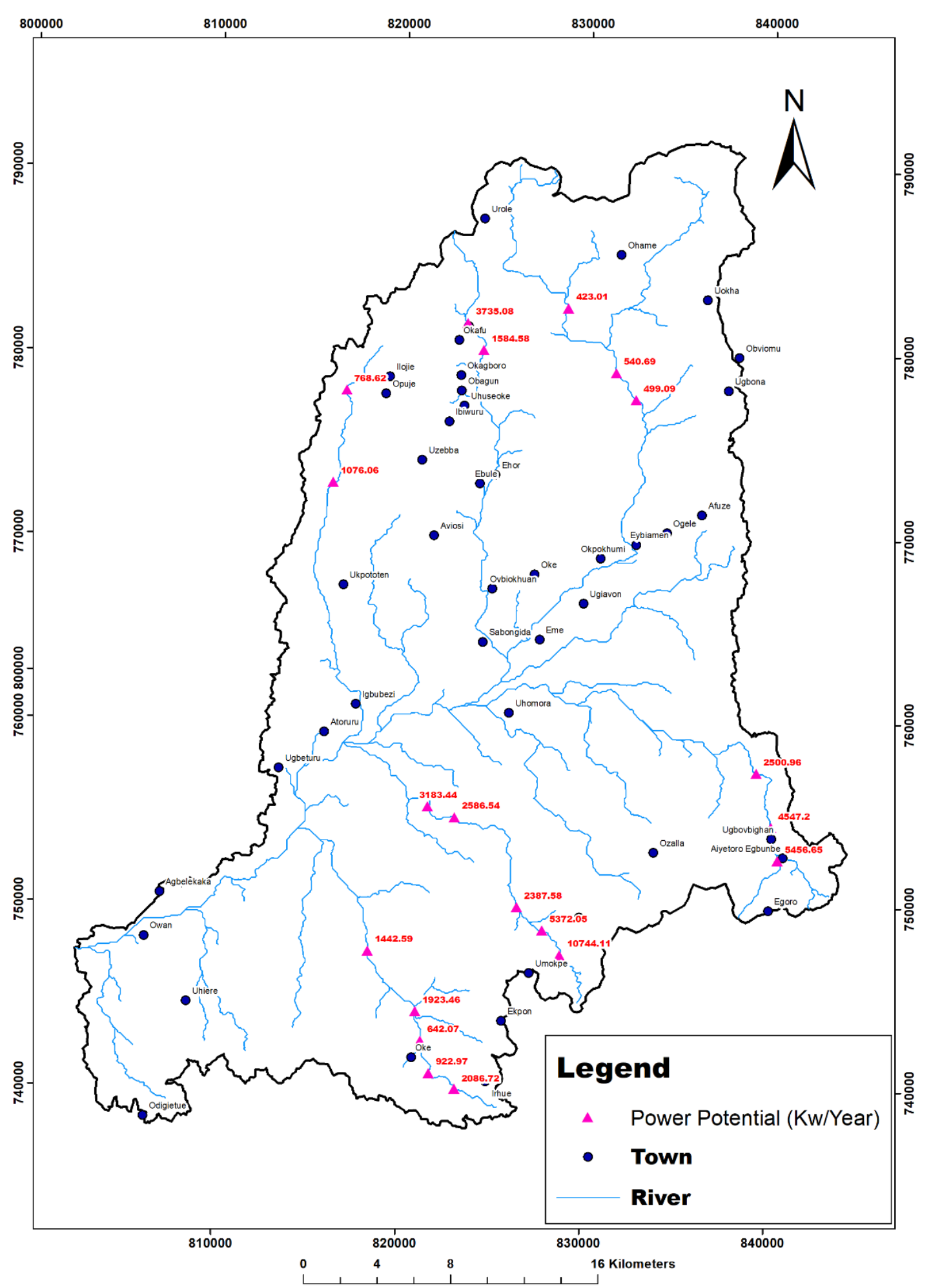

Figure 27: Owan Catchment SHP potential Location

\subsection{Conclusion}

The method utilized in this paper creates a process that is free from error by requiring specific data that are obtained from RS and GIS that best copy and reproduces the Owan catchment sufficiently for example rainfall, CN, DEM where slope and elevation were derived. Other physiographic characteristics assessed in the sub-basin includes catchment area, stream network length, discharge capabilities. From this study the following conclusions are made:

[1] This approach is better and faster compared to traditional practice where different types of equipment are utilized independently to acquire various topographic data. 
[2] The combination of NRSC-CN model, RS, and GIS shows high dependability status when paired for evaluation of run-of-river (ROR) discharge vis-a-vis SHP potential.

[3] The estimated power potential calculated in $\mathrm{kW}$ for each viable location considering the catchment features (Slope and elevation) indicates the sites are qualified to yield such energy.

[4] The success achieved in this research can be attributed to the utilization of accurate terrain data resources and high-resolution images. This enhances the investigation by producing good correlation results for both discharge and rainfall.

[5] Satellite-based RS application has advantages like large area coverage, synoptic view, and capability to provide information over all accessible and inaccessible regions.

[6] Adequate topographic conditions exist in which the water resources of Owan river can be utilized to generate power either as an off-grid or on-grid system

[7] The power available at $92 \%$ exceedance of the viable 20 hydrological points identified as SHP potential locations ranges between $423.015 \mathrm{~kW}$ to $5,456.646 \mathrm{~kW}$

\section{Acknowledgements}

The authors express sincere gratitude to the Department of Civil Engineering, University of Benin, Benin City, Edo State, Nigeria; Benin-Owena River Basin Development Authority (BORBDA), and Engr. Adelowo, Adereti for their kind cooperation and Support.

\section{References}

Avila, C.J.C.P., Júnior, O.A.C., Guimarães, R.F., Bentancurt, J.J.V. (2007). Preliminary survey of undeveloped hydropower potential using GIS-based tools [Use of GIS tools for preliminary inventory of remaining potentials]. Technical paper: National Reference Center for Small Hydroelectric Plants. Department of Geography, University of Brasilia. Available at, http://www.cerpch.unifei.edu.br/at01.php?grp

Bala, E.J. (2019). The Role of SHP in Nigeria's Energy Policy. Paper Presented at the Capacity Building Workshop on Small Hydro Power Development for Policy Makers and Renewable Energy Project Developers In Nigeria Under The Framework Of The GEF-5 Project "Scaling Up Small Hydro Power In Nigeria" Organized By United Nations Industrial Development Organization (UNIDO), Nigeria, $28^{\text {th }}$ October 2019 at Barcelona Hotel, Abuja.

Ballance, A., Stephenson, D., Chapman, R. A., \& Muller, J. (2000). A geographic information systems analysis of hydro power potential in South Africa. Journal of Hydroinformatics, 2(4), 247-254.

https://doi.org/10.2166/hydro.2000.0022

Bennui, A., Rattanamanee, P., Limjirakhajorn, K., Yongsatitsak, T., Yongchalermchai, P., Yisuwan, C. (2012). Application of Geo-informatics on assessment of mini-hydropower potential in Khao Luang mountain range, Nakhon Si Thammarat Province. 33rd Asian Conference on Remote Sensing 2012, ACRS 2012. 1. 719-731.

BORBDA (1992), Benin Owena River basin Hydrological year Book, 1989-1990

BORBDA (1993), Benin Owena River basin Hydrological year Book, 1991-1992

BORBDA (1997), Benin Owena River basin Hydrological year Book, 1993-1994

BORBDA (2005), Benin Owena River basin Hydrological year Book, 1995-1998

BORBDA (2007), Benin Owena River basin Hydrological year Book, 1999-2000

Chandra, B. A., Giridhar, M. V. S. S., Venkateswar, R. C., \& Viswanadh, G. K. (2013) Identification of Suitable Locations for Micro Hydro Power Stations Using Geospatial Technology. In World Environmental and Water Resources Congress: Showcasing the Future (pp. 1377-1381). ASCE.

Connolly, D., MacLaughlin, S., \& Leahy, M. (2010). Development of a computer program to locate potential sites for pumped hydroelectric energy $\quad$ storage. Energy, 35(1), $375-381$. https://doi.org/10.1016/j.energy.2009.10.004

Czitrom, V. and Spagon, P., (1997). Statistical Case Studies for Industrial Process Improvement. Philadelphia, Pa.: Society for Industrial and Applied Mathematics (SIAM, 3600 Market Street, Floor 6, Philadelphia, PA 19104) p. 342.

Dudhani, Surekha \& Sinha, A.K. \& Inamdar, S.S., (2006). "Assessment of small hydropower potential using remote sensing data for sustainable development in India," Energy Policy, Elsevier, vol. 34(17), pages 31953205, November.

ECN. (2014). Draft National Renewable Energy \& Energy Efficiency Policy (NREEEP) 2014 Ed. Energy Commission of Nigeria Available: http:/www.energy.gov.ng/.

ESHA/IT-Power, (2006). "Small Hydropower for Developing Countries". European Small Hydropower Association. Belgium 2006. www.esha.be

FAO (2008). Water for Agriculture and Energy in Africa: The Challenges of Climate Change. Report of the ministerial conference 15-17 December 2008, Sirte, Libyan Arab Jamahiriya. Available at: www.fao.org/docrep/014/i2345c01.pdf (last accessed 28 May 2016). 
Fasipe, O., \& Izinyon, O. (2020). GIS and RS Techniques for Identification of Hydropower Potential Sites in Benin-Owena River Basin in Nigeria. INTERNATIONAL JOURNAL of RENEWABLE ENERGY RESEARCH O. Fasipe and O. Izinyon, 10(1), 486-498.

Feizizadeh, B., \& Haslauer, E. M. (2012). GIS-based procedures of hydropower potential for Tabriz basin, Iran. International Journal, 495-502.

Hall, D.G., Cherry, S.J., Reeves, K.S., Lee, R.D., Carroll, G.R., Sommers, G.L., et al (2004). Water energy resources of the United States with emphasis on low head/low power resources. US Department of Energy. Available at: http://hydropower.id.doe.gov/resourceassessment/pdfs/03-11111.pdf

International Journal on Hydropower and Dams (IJHD), (2015). World Atlas \& Industry Guide, IJHD Wallington, ISO 1100-2, 1998, Measurement of liquid flow in open channels - Part 2: Determination of the stagedischarge relation Surrey.

Kusre, B. C., Baruah, D. C., Bordoloi, P. K., \& Patra, S. C. (2010). Assessment of hydropower potential using GIS and hydrological modeling technique in Kopili River basin in Assam (India). Applied Energy, 87(1), 298309. https://doi.org/10.1016/j.apenergy.2009.07.019

Larentis, D. G., Collischonn, W., Olivera, F., \& Tucci, C. E. M. (2010). Gis-based procedures for hydropower potential spotting. Energy, 35(10), 4237-4243. https://doi.org/10.1016/j.energy.2010.07.014

Li, M.H., \& Chibber, P. (2008). Overland Flow Time of Concentration on Very Flat Terrains. Transportation Research Record: Journal of the Transportation Research Board,2060(1), 133-140. https://doi.org/10.3141/2060-15

MNRE, (2008). Government of India standards/manuals/Guidelines for small hydro development: manual on project Hydrology and installed capacity. Ministry of New and Renewable Energy Available from: http://www.iitr.ac.in/PageUploads/files/2_3_GUIDELINESFOR_STRUCTURAL_DESIGN_OF_SHP_PR OJECTS.pdf.

OCHIGBO, A.J. (2019). Resource Potential, Challenges and Suggestions for Efficient Exploitation of Small Hydropower in Nigeria. A Paper Presented at Capacity Building Workshop on Small Hydropower Development for Policy Makers and Renewable Energy Developers In Nigeria Held on 28thOctober, 2019 at Barcelona Hotel, WuseII, Abuja.

Oyedepo, S. O., Babalola, O. P., Nwanya, S. C., Kilanko, O., Leramo, R. O., Aworinde, A. K., Adekeye, T., Oyebanji. J. A., Abidakun, A. O. and Agberegha, O. L. (2018). Towards a Sustainable Electricity Supply in Nigeria: The Role of Decentralized Renewable Energy System. European Journal of Sustainable Development Research, 2(4), 40. https://doi.org/10.20897/ejosdr/3908

Panlenlab, (2017). New Paper In Canadian Journal Of Fisheries And Aquatic Sciences: Run-Of-River Hydropower And Salmonids - Potential Effects And Perspective On Future Research. [online] Palen Lab. Available at: $\quad<$ https://palenlab.wordpress.com/2017/10/11/run-of-river-hydropower-and-salmonidspotential-effects-and-perspective-on-future-research/> [Accessed 23 September 2020].

Pandey, Ashish, Daniel Lalrempuia \& S.K. Jain (2015) Assessment of hydropower potential using spatial technology and SWAT modeling in the Mat River, southern Mizoram, India, Hydrological Sciences Journal, 60:10, 1651-1665, DOI:10.1080/02626667.2014.943669)

Pukelsheim, F. (1994). The Three Sigma Rule. The American Statistician, 48(2), 88. https://doi.org/10.2307/2684253

Rojanamon, P., Chaisomphob, T., \& Bureekul, T. (2009). Application of geographical information system to site selection of small run-of-river hydropower project by considering engineering/economic/environmental criteria and social impact. Renewable and Sustainable Energy Reviews, 13(9), 2336-2348. https://doi.org/10.1016/j.rser.2009.07.003

Roussel, M.C., Thompson, D.B., Fang, Xing, Cleveland, T.G., and Garcia, C.A. (2005). Time-parameter estimation for applicable Texas watersheds: Texas Department of Transportation Research Report.0-46962: Beaumont, Texas, Lamar University.

Sahu, S. (2015). Small Hydropower: Feasible Location, Potential and Installation in Odisha. M.Tech. Thesis National Institute of Technology, Rourkela, India.

Salimi, E., Nohegar, A., Malekian, A., Hoseini, M., and Holisaz, A. (2016). Estimating time of concentration in large watersheds. Paddy and Water Environment, 15(1), 123-132. https://doi.org/10.1007/s10333-016-05342.

Smakhtin, V. (2001). Low Flow Hydrology: A Review. Journal of Hydrology, 240(3-4), 147-186. https://doi.org/10.1016/s0022-1694(00)00340-1

Šraj, M., Dirnbek, L., \& Brilly, M. (2010). The influence of effective rainfall on modeled runoff hydrograph. Journal of Hydrology and Hydromechanics, 58(1). https://doi.org/10.2478/v10098-010-0001-5

Taulo, J.L. (2007). A Study on the Utilization of Small-Scale Hydropower for Rural Electrification in Malawi. M.Sc. Thesis, University of Cape Town, South Africa.

The Nigerian Energy Support Programme II (NESP, 2019). Fostering Investments for Renewable Energy and 
Energy Efficiency and Improving Access to Electricity for Disadvantaged, Rural Communities.

Travers, J., Cook, B., \& Cook, L. (2017). Null Hypothesis Significance Testing and p Values. Learning Disabilities Research \& Practice. https://doi.org/10.1111/ldrp.12147

US Natural Resources Conservation Service (NRCS) (1997) Ponds planning, design construction. In: Agriculture handbook. United States Department of Agriculture (USDA)

Vemu, S., and Bhaskar, P. (2010). Estimation of Catchment Characteristics using Remote Sensing and GIS Techniques. International Journal of Engineering Science and Technology, 2(12), 7763-7770.

Verma, S., Verma, R. K., Mishra, S. K., Singh, A., \& Jayaraj, G. K. (2017). A revisit of NRCS-CN inspired models coupled with RS and GIS for runoff estimation. Hydrological Sciences Journal, 62(12), 1891-1930. https://doi.org/10.1080/02626667.2017.1334166

Viji, R., Prasanna, P.R., \& Ilangovan, R. (2015). GIS Based SCS - CN Method for Estimating Runoff in Kundahpalam Watershed, Nilgries District, Tamilnadu. Earth Sciences Research Journal, 19(1), 59-64. https://doi.org/10.15446/esrj.v19n1.44714

Yi, C.-S., Lee, J.-H., \& Shim, M.-P. (2010). Site location analysis for small hydropower using geo-spatial information system. Renewable Energy, 35(4), 852-861. https://doi.org/10.1016/j.renene.2009.08.003

Yu, P, Yang, T and Wang, Y. (2002). “Uncertainty Analysis of Regional Flow Duration Curves.”Journal of Water Resources Planning and Management128: pp 424-430.

Olatubosun Fasipe obtained his B.Eng. in Civil Engineering from the Federal University of Technology Akure in 2007. He bagged a Master's degree in 2014 and currently on the verge of completing his Doctoral research in Civil Engineering (Water Resources and Environmental Health Engineering option) from the University of Benin, Benin City, Edo State a seasoned and reputable institution in Nigeria. Before joining the Energy Commission of Nigeria (ECN) in 2011, he worked with some indigenous construction /oil and gas companies where he acquired sound knowledge of civil works and construction management. He has attended many training programs, both local and international, on hydropower systems and He is currently a Senior Scientific Officer at ECN. His responsibility is not only limited to hydropower projects but also to quantify energy needs with a view of establishing a baseline for energy use or need sustainably. He holds membership in numerous professional bodies which include the International Association of Engineers (IAENG), World Society of Sustainable Energy Technologies (WSSET), Nigerian Society of Engineers (NSE), Council for the Regulation of Engineering Profession in Nigeria (COREN) to mention few.

Osadolor Izinyon is a Professor of Water Resources and Environmental Engineering at the University of Benin, Benin City Nigeria. He holds a Bachelor of Engineering degree in Civil Engineering and Masters and Doctorate degrees in Water Resources and Environmental Engineering. His research interests are in Hydrology, Water Resources, Hydraulic Structures and Sustainable Development. He has attended Professional courses both local and international. Professor Izinyon attended the short course on Predictions in Ungauged Basin at the UNESCOIHE Institute for Water Education, Delft Netherlands in 2015. In 2017, he won the MASHAV fellowship to attend the International Course in Addressing the Urbanization Challenge at the Weitz Centre for Sustainable development, University of Jerusalem, Israel. Professor Izinyon is a fellow of the Nigerian Institution of Civil Engineers (FNICE), Member Nigerian Society of Engineers, Member Nigerian Committee on Large Dams (NICOLD). He is registered by the Council for the Regulation of Engineering Profession in Nigeria (COREN).

Chukwudi Emeribe graduated from Geography Department, University of Nigeria and holds an MSc, Hydrology /Water Resources Management. He has been part of many research and consultancy services including, Hydropower potentials of Rivers in Edo State, Suitability study for Jatropha curcus cultivation in Edo State using hydro-climatic indices, Water quality profiles of Rivers in Edo and Delta State, World bank sponsored projects on Environmental and Social Impact Assessment (ESIA) and Resettlement Action Plan (RAP) for erosion affected areas in Edo State. He a research member for the Centre for Global Eco-innovation, CGE Nigeria, a University of Benin-Lancaster University Research Model to promote Academia-Industry synergy (Water and Energy).

Idowu Ilaboya holds a Higher National Diploma (HND) with distinction in Polymer Technology (Auchi), post graduate diploma (PGD) with distinction in Chemical Engineering (FUTMINNA), master's degree (M. ENG) with distinction in Water Resources and Environmental Engineering (UNIBEN) and a doctorate degree (Ph.D.) in Water Resources and Environmental Engineering (UNIBEN). He is a recipient of the Alumni Merit Award for best National Diploma student in Polymer Technology (1996), recipient of the Rector's Merit Award for best HND student in School of Applied Science and Technology (1999), best graduating student PGD Chemical Engineering (2001), best graduating student M. ENG Civil Engineering (2012), University of Benin annual research award winner for Faculty of Engineering (UBARD 2016 and 2018). Currently, Dr. I. R. Ilaboya is a lecturer in the Department of Civil Engineering with specialization in Water Resources and Environmental Management, Hydrologic Modelling, Statistical Analysis, Air pollution, and Environmental systems optimization. He is a COREN registered Engineer (R55762) and member; Nigerian Society of Engineers (NSE), Nigeria Institution of Professional Engineers and Scientist (NIPES), Nigeria Association of Hydrological Sciences (NAHS), Nigerian 
Association of Technologist in Engineering (NATE), Materials Society of Nigeria (MSN) and Polymer Institute of Nigeria (PIN). Engr. Dr. I. R. Ilaboya is a Research member: University of Benin Center of Excellence in Water Science and Technology, a NEPAD/EU funded program. He has over 60 publications in local, national, and foreign journals.

Victor Eniola is a corporate member of the Nigerian Institution of Mechanical Engineers (NIMechE), and a registered Engineer with the Council for Regulation of Engineering in Nigeria (COREN). He graduated from Naresuan University, Thailand, where he obtained a Master of Science degree with High Distinction in Renewable Energy. Eniola completed his undergraduate study with First Class Honours in Mechanical Engineering from Obafemi Awolowo University, Nigeria and worked as a Teaching Assistant in University of Benin before joining the Energy Commission of Nigeria (ECN) in 2013. He attended a training program on Conducting Feasibility Studies for Small Hydro Plant organized by Renewables Academy (RENAC), Germany. In his quest for professional expertise, he has attended many other international training and conferences; including the international training program on Renewable Energy as a Catalyst for Regional Development organized by MASHAV, Israel's Agency for International Development Cooperation. Eniola is currently a Senior Scientific Officer in ECN, actively involved in cutting-edge research in the area of renewable energy technologies. His cognate experience and academic prowess have earned him a Teaching/Research Assistant Doctoral scholarship of the Energy Technology for Environment Research Centre, Faculty of Engineering, ChiangMai University, Thailand.

Ebuwa Isagba, holds a bachelor's degree in Civil Engineering and a master's in water resources and environmental engineering. Her research interests are clean sustainable energy (small hydropower, bioenergy) and climate change, she has worked on hydropower potential of streams in southern Nigeria. She is presently working on utilizing organic waste to achieve biofuel and sustainable biofertilizer. She is a registered engineer (COREN) and a member of Nigeria Society of Engineers. She is part of the University of Benin Research Team, Centre of Excellence in Water Science and Technology, a NEPAD funded Programme and research personnel with Centre for Global Ecoinnovation, CGE Nigeria, a University of Benin-Lancaster University Research Model to promote AcademiaIndustry synergy (Water and Energy)

Nicholas Uwadia has a B.Sc. in Geology from the University of Benin and holds M.sc in Environmental Geology. He has been involved in research and consultancy in the areas of Geostatistics, Landscape Morphological modeling, Climate change, and Watershed analysis. Major research interests include application of Open-source models in Environmental modeling. He is a member of the Nigerian Association of Hydrological Sciences (NAHS), Member of Community surface Dynamics Modelling System (CSDMS) in the USA. 